\title{
MEANING OF THE TERMS AMNESTY AND PARDON IN THE MACEDONIAN CRIMINAL LAW
}

\author{
Nada Simjanoska, PhD, \\ Head of department in Ministry of Justice, 1000 Skopje, +38975-390-368 \\ nadasimjanoska@yahoo.com
}

\section{Professional Paper doi:10.5937/jouproman5-12840}

\begin{abstract}
From ancient times and on, the amnesty and the pardon represent an act of grace, term of highest grace that provides the necessary safety valve of justice. It is expected from the amnesty and pardon to ensure that justice will became more humane despite the high inflexibility of the laws. It is expected to be taken into account the hesitation left after few verdicts, although all of the effective verdicts, in principle, are connected with the invincible legal assumption that they have been legitimate.
\end{abstract}

The purpose of this research is through some examples in the Macedonian law to achieve more detailed explanations i.e. analysis of the terms amnesty and pardon. At the beginning of this study are shown the definitions of amnesty and pardon, the review of the laws related to the amnesty and pardon in the Macedonian criminal law, and at the end with reference thereto to be presented the legal framework within our country, i.e. in the Macedonian criminal law and the ways which these terms can be realized in.

This study is an attempt to confirm that Macedonia will keep on fulfilling the international principles on human rights, and its obligations according to the international agreements, with the aim to protect and to promote the situation of its citizens.

Key words: Amnesty, pardon, abolition, criminal law, president, claim.

\section{Introduction}

The justification of the terms amnesty and pardon can be seen by many aspects. Namely, the justification can be found in some special national(political) interests, for e.g. one person to be caught ,in flagranti“" in an espionage, and yet the state is not willing to compromise its good relations and collaboration with the country to which the spy belongs to by taking him to court and serve the sentence. Furthermore, the justification of these legal terms can be found in the interest of the nation for e.g. when the character of the delinquent is associated with personal benefits from the past and is having great perspective in the future by his exceptional talent (music, sport activities, literature etc.) offering to the nation.

From the other side, the definition or the process of abolition, represents releasing of the perpetrator from legal prosecution by means of amnesty and pardon. The abolition means to disable the legal prosecution against the perpetrator of the criminal act or to disable its continuance if the process is already ongoing. The court takes decision for abolition to terminate the legal prosecution and if the defendant is in detention, he is to be released. The abolition can be granted in every stage of the criminal process as well as before this process up to the effectiveness of the court decision.

In some cases when due to changes in the social-economic or political circumstances in the country it becomes fully injustice, or even absurd, to insist on execution of certain effective verdicts (for e.g. here we can mention criminal acts being annulated in meantime).

Is there any sense to insist on execution of a decision referring to already annulated criminal acts for which the society itself has assessed that such acts do not endanger it. 
Considering the changes in the society (economic and political), as well as in everyday life, we can conclude that the changes regarding the acceptance of amnesty and pardon are necessary.

\section{Definition of amnesty and pardon}

Amnesty and pardon consist of penalty cancelation for the perpetrator of the criminal act granted by the appropriate records brought into decision by the highest governmental bodies. ${ }^{1}$ By an amnesty and pardon you can cancel the penalty being effective or release him from being prosecuted or punished. In the first case it means that there is amnesty, i.e. pardon in a narrower sense, while the later means amnesty or pardon in the wider sense of word or abolition.

Both the amnesty and the pardon are very old terms. They are known in the Roman law, as well as in the medieval law. For the justification of these two terms there were many opposite opinions. Especially they have been disputed by the representatives of the old-school. It has to be highlighted that these have been used throughout the history for a misuse, to disturb the justice execution based on the laws, to unreasonable favour any individual delinquents etc. These critics came from the medieval practice in using these facilities, i.e. terms, and this especially refers to pardon.

The fact that these terms have been misused in the past for political purposes, cannot deny their extraordinary useful part. There are numerous reasons to justify the social use of existing and application of these terms. $^{2}$

First of all, there is a possibility in some cases that the court may take a bad decision based on a mistake presented in

\footnotetext{
1 Marjanovik Gorgi, Makedonsko krivicno pravo, opst del, Prosvetno delo, 1998, Skopje

${ }^{2}$ Kovalev M. i kolektiv avtorov, Ugolovnoe pravo, ossobenaja cast, NORMA, 2001, Moskva
}

some facts and circumstances or based on false statements, so the amnesty and pardon resulted as exceptionally corrective measures to remove these unjustly verdicts. Then, it is possible that due to economic and political changes, the criminal act may lose its social risk which makes it unjustly to punish the perpetrator for such act. In such cases the amnesty and the pardon are very good, i.e. appropriate measures to annulate the sentence and to stop from prosecution of the perpetrator of such acts. ${ }^{3}$

In some cases, it is necessary to grant pardon to certain people for the act they've taken because of the reasons such as humanity or due to social, national and political reasons. This is in case they have extraordinary credits for a certain socialpolitical community. At the end, the amnesty and pardon present a special incentive for governance and for recovery of the convicts, as well as a special reward for their well behaviour. ${ }^{4}$

Apart from the pardon, the amnesty is an act that in form of a law is being brought by the Parliament, which grants to an undefined number of persons release from being prosecuted, full or partial release from execution of the penalty, replacing of the penalty with a more favourable one or annulation of the legal consequences from the verdict.

This definition sets the three basic elements of the amnesty: ${ }^{5}$ it is an act from the highest representative body; it refers to unlimited number of persons; and it consists of release from prosecution, partial or full execution of the penalty or annulation of the legal consequences from the verdict.

\footnotetext{
3 Đurcevic, Z., Povijesni razvoj kaznenopravnog položaja pocinitelja $\mathrm{s}$ duševnimsmetnjama u Engleskoj, Zbornik PFZ, vol. 56, broj 2-3, 2006.

${ }^{4}$ Bacic, F., Krivicno pravo, opci dio, Zagreb, 1980.

${ }^{5}$ Ljubisa Jovanovik, Krivicno pravo, opst del, Naucna knjiga, Beograd, 1969
} 
By the activation of the amnesty and pardon you annulate the penalty, but you don't suspend the safety measures nor the educative measures. This is because the safety measures and the educative measures have the purpose to a recovery and education of the convicted person who is granted amnesty or pardon. These can act on the prosecution sanctions only if they are given in a form of abolition, because then, due to the inability to press criminal charges, i.e to terminate the criminal process, such measures cannot be sentenced. ${ }^{6}$ By an amnesty and by pardon you cannot annulate the verdict, nor you can annulate the criminal act, but you only do unconditional remission of the penalty with the effective verdict.

By granting pardon and amnesty, you don't affect the right of third parties to which the verdict is based on. Each injured person has the right to, respectfully of the amnesty i.e. pardon, ask for execution of additionally imposed damage. By an abolition there is no verdict for a criminal act, therefore, the question is, does this affect the third persons' rights, resulting from the executed criminal act. It is considered that neither in this case the third persons' rights can be affected, because these result from the criminal act which is a fact, so these can be achieved or realized without presence of any appropriate verdict. $^{7}$

The amnesty and pardon can be used for criminal-political purposes, as well as for political purposes only. They present a political act of grace, and are brought by the high national bodies, by the Parliament and the Chief of State i.e. by the President. This means that the decision for amnesty and pardon of certain person or many persons is for a political nature (interest), and the benefit of its appliance is only to those to whom this refers to. Also, after bigger war conflicts, such acts of amnesty and pardon are being brought as a pacification i.e. as an act of reconciliation between the two opponent parties.

That was the case with the amnesty of the former members of the Albanian National Army (ONA) after the conflict in 2001 in the Republic of Macedonia. It was adopted the Law on Amnesty which come into force on 8 March 2002. Therewith, it enables release from prosecution of, stop the criminal processes and fully release from being held in prison of persons for which there is a suspicion they've been involved in arranging or performing criminal acts related to the conflict in 2001. The Public prosecutor cannot file a claim against the decision by which the person is granted amnesty. By adoption of the interpretation of the cases „ONA's leadership“, „Neprosteno“, „Mavrovo’s workers“" and „Lipkovodam“, which have been returned in Macedonia by the Court in Hague, stops the investigation and the court process.

This was a voluntary solution and an act of reconciliation in the time of ethnic and political confusion by showing a practice in which everyone in Republic of Macedonia saw a hope for a brighter future.

By the amnesty it was striven to solve or at least to mitigate certain social or political issues. So, politically motivated amnesty is commonly used after bigger incidents, riots and social conflicts aiming to set the social law and order. In such cases, the amnesty is an instrument of pacification.

\footnotetext{
${ }^{6}$ Đurcevic, Z., Povijesni razvoj kaznenopravnog položaja pocinitelja $\mathrm{s}$ duševnimsmetnjama $\mathrm{u}$ Engleskoj, Zbornik PFZ, vol. 56, broj 2-3, 2006.

${ }^{7}$ Henigsberg, L., Tumac zakonika o sudskom krivicnom postupku za Kraljevinu Srba, Hrvata i Slovenaca od 16. februara 1929, Zagreb, 1930. 


\section{The term amnesty in Macedonian criminal law}

The amnesty is brought in form of a Law, so it represents an universal act. Determination of people entitled to amnesty can be performed in several ways. So, in the act of amnesty it can consist of the criminal acts for which the perpetrators are being released from prosecution and punishment or serving the sentence fully or in part. Then, an amnesty can be granted by determination of the type and time of the sentence. For e.g. amnesty for all people serving a prison sentence of up to six months, or to all people serving a prison sentence up to ten years provided they have spent eight years in prison. ${ }^{8}$

Release from prosecution, in theory known under the term abolition, represents a special type of amnesty. The abolition disables commencement of the criminal process itself, or its continuance. In case of adoption of an act of abolition, the criminal process is being terminated, if such already started, the persons covered by the abolition are being released from detention or released free from jail. The abolition can be given in every stage of the process up to the effectiveness of the court decision. Its action is the highest, because there is no final verdict, so the perpetrator of the act doesn't suffer any legal consequences, nor the act for which abolition is granted can be taken as a ground to re-start the process. ${ }^{9}$

Therefore, the amnesty as such can mean fully or partially release from penalty: ${ }^{10}$ the full release from execution of the penalty covers every penalty, the main as well as the additional penalties. The partially release from execution of the penalty covers only some of the penalties or

\footnotetext{
${ }^{8}$ Kambovski Vlado, Kazneno pravo, poseben del, Prosvetno delo 2003, Skopje, cit.delo 6

${ }^{9}$ Kurtovic, Š., Impeachment i politicka odgovornost, Studije i clanci iz opce povijesti prava i drzave 1962-2002, Zagreb, 2002.

${ }^{10}$ Kambovski Vlado, Problematikata na propustanjeto vo kaznenoto pravo, 1982, Skopje
}

can result with decrease of the penalty. By amnesty you can replace the sentence with a more favourable one. But the amnesty cannot change the unconditional sentence into probation, having in mind that the amnesty refers to an undefined number of cases, while the probation is given based on an assessment for each specific case. The amnesty can refer to annulation of the legal consequences from the verdict, so the persons obtain all the right which have been suspended by law.

\subsection{Amnesty application in Republic of Macedonia}

The Law on amnesty defines that the procedure, against the persons subject to a criminal process for which this law applies, shall be led under jurisdiction from the competent public prosecutor, i.e. the competent primary court or the persons to whom the amnesty refers to, i.e. person who can file a claim on behalf of the defendant.

According to the adopted interpretation, the article 1 of the Law on amnesty should be interpreted such as the amnesty shall apply to all perpetrators of criminal acts related to the conflict in 2001 including and up to 26 September 2001, except to persons committed criminal acts related to the conflict, against whom the International Tribunal commenced the process. ${ }^{11}$ The cases „ONA's leadership“, „Neprosteno“, „Mavrovo's workers“ and „Lipkovo dam“ have been processed by the International Court of Justice in Hague, but these cases have been returned in 2008 under jurisdiction of the Macedonian courts. By adoption of the authentic interpretation of the Law on amnesty, the Parliament has decided in July 2011 to stop the criminal prosecution of the responsible persons, under suspicion for war crimes from 2001, for the four „Hague's cases“.

\footnotetext{
${ }^{11} \mathrm{http}: / /$ denesen.mk/web/?p=73095
} 
In Republic of Macedonia there is no trial for war crimes. The Law on amnesty, adopted in 2002, enabled the amnesty of all members of armed formations, which were under suspicion to commit criminal acts during the conflict including and up to 26 September 2001. According to this law, the amnesty doesn't refer to acts for which a process is being started in front of the MKSJ. On 19 July 2011, under initiative of the Albanian political parties (Democratic Party of Albanians - DPA and the Democratic Union for Integration - DUI) started the process of authentically interpretation of the Law on amnesty by the Parliament of the Republic of Macedonia. On the same day, this initiative was adopted by 63 votes "for" and 29 "against", which practically terminated the prosecution justice for severe breach of the human rights during the armed conflict in Macedonia. The authentic interpretation of the Law on amnesty enabled the amnesty to apply to the suspects and to the defendants in the cases which MKSJ has previously returned to Republic of Macedonia for processing.

\section{The term pardon in Macedonian criminal law}

The pardon represents an act brought by the President of the Republic, or of the Parliament, an act through which to individual persons are granted release from prosecution, fully or partially release from serving the sentence, replace the sentence with a more favourable one or of cancelation i.e. annulment of all legal consequences from the verdict. The pardon consists of the following elements: ${ }^{12}$ it is granted from the highest national bodies of the national authorities determined by law; it refers to certain number of designated persons being convicted; the content of the pardon consists of release from prosecution

\footnotetext{
${ }^{12}$ Kurtovic, A.: Pomilovanje u kaznenom pravosudju (u povodu novoga Zakona o pomilovanju), Hrvatski ljetopis za kazneno pravo i praksu (Zagreb), vol. 10, br. 2, 2003.

or from serving the sentence, change of the sentence, or cancelation or annulations of the legal consequences resulting from the verdict.

The pardon refers to designated persons being convicted, meaning that in the act of pardon you can indicate only one person or you can indicate more persons with their first and last name, as well as with other personal details of the convicted persons i.e. of persons for which the adopted act of pardon refers to. ${ }^{13}$ The content of the pardon is totally the same as the content of the amnesty i.e. by pardon it can be granted abolition, full (complete) or partially release from execution of the penalty from the verdict, replace the sentence with a more favourable one i.e. shorter sentence and to annul (cancel) the legal consequences from the verdict.

\subsection{Pardon application in Macedonian criminal law}

The reasons for adoption of the Law on amendment and modification of the Law on pardon ${ }^{14}$, first of all, come from the weaknesses and gaps in the applicable law, which arise from its application in practice, the need to specify in details the norms of the appropriate issues as regulated by law, as well as from the more appropriate legal regulation of this matter. Furthermore, due to the urgent necessity of the process the law itself envisages the deadlines for treatment by the participants in the previous process, and also a terminological adjustment of specific names and definitions has been made.

According to the applicable Law on pardon, the President of the Republic of Macedonia may grant a pardon to a designated person the perpetrator criminal act as defined under the laws of Republic of Macedonia according to the provisions of the Criminal Code and the provisions of the Law.

\footnotetext{
${ }^{13}$ Marjanovik Gorgi, Makedonsko krivicno pravo, opst del, Prosvetno delo, 1998, Skopje

14“"Sluzben vesnik na RM”,br. 20/93
} 
It is defined by Law the process of pardon, the possibility of an authorized type of people to submit an application for pardon, and to re-apply for a pardon after the deadline from the decision according to the previous application expires. The Law also regulates the obligation and the authorization of the court and the penitentiary to immediately conduct the so called pre-process for pardon, to send to the Ministry of Justice the preparatory information and documents in order the decision to be brought. The Minister of justice gives his proposal together with the completed documents for the decision to the President of the Republic of Macedonia.

\subsection{Meaning of the pardon}

The pardon as a term is significant for the executive government to monitor the court decisions, as well as to mitigate (decrease) and to annul i.e. to cancel such. Actually, the act of pardon has a function of a special legal norm which derogates the general legal norm. If by the act of pardon "in concreto" is decided for the use of the direct (automatic) appliance of the law (in case of legal consequences from the verdict for which it is not necessary nor possible to adopt some special judicial or any other legal act), by the act of pardon as such... „derogates" the law itself i.e. the possibility of its specific appliance is excluded in that part referring to the specific legal consequence from the verdict." ${ }^{\text {"15 }}$

Furthermore, some authors consider the pardon as significant, because it removes the legal consequences from the verdict, i.e. the pardon releases all or some of the court sentences for the convict, or the perpetrator of the criminal act, but this doesn't suspend the verdict and the penalty, because as the authors indicate, this can be made by the Court of Appeals only. ${ }^{16}$ The formal integrity of the court decision cannot

\footnotetext{
${ }^{15}$ Pihler, S., Prilog o raspravi o pomilovanju, Pravni zivot, br. 6-7, 1987

${ }^{16}$ Rassat, Michcle-Laure, Droit pénal, Presses Universitaires de France, Paris, 1987
}

be derogated by the act of pardon, but the pardon constrains the lawfully punishment of the perpetrator of the criminal act i.e. the pardon does not plea the convict innocent. The conclusion resulting from this is that the pardon doesn't annulate the court decision for the guilt of the person convicted for the committed criminal act.

The meaning of the pardon is that the pardon does not convert the court decision in the part referring to the penalty decision. Although the pardon represents a judicial act, this doesn't deny its influence on the judiciary. ${ }^{17}$ The act of pardon provides release from execution of the penalty, but it doesn't release from the sentence as such which is still going to be sentenced, but its integrity shall not be affected. Furthermore, Geerds highlights the importance of the pardon, because it presents a legal obstacle in execution of the effective verdict. ${ }^{18}$ The opposite opinion has Frank, who claims that the pardon may fully annulate the penalty. ${ }^{19}$

The pardon is important as a legal term for penalization, because it has a powerful legal influence. The act of pardon is "de facto" stronger than the verdict and derogates such. Therefore, the act of pardon represents a powerful tool of the executive government, and in the English-saxon legislation this is a basic term to perform "cheks and balances" of the executive government in the system of interconnected control of the separated powers.

In general, the act of grace is based on the protection of the social interest. These are legal instruments which grant grace to convicts unable to obtain it in another way. The amnesty and the pardon are very important political tools for the benefit of the state for de-penalization which in certain political moments exceed the interest of the state for penalization.

\footnotetext{
${ }^{17}$ Geerds, F., Gnade, Recht und Kriminal politik, J.C.B. Mohr \& Paul Siebeck, Tübingen, 1960.

${ }^{18}$ Geerds, F., Gnade, Recht und Kriminal politik, J.C.B. Mohr \& Paul Siebeck, Tübingen, 1960.

${ }^{19}$ Frank, S., Teorija kaznenog prava, Zagreb, 1955.
} 
The pardon is significant, because it has more functions in the legislation of almost every state. The pardon may have the function to correct the judicial mistakes. In case of failure of the criminal law due to its system of generality, or universality, the pardon may have the function for righteous and to improve the imperfection and the rigidity of the criminal law. ${ }^{20}$

Of course, in some individual cases of pardon, it serves as a powerful instrument for resocialization and rehabilitation of the convicts, which is one of the most important functions of the pardon, but here it is often confused with the probation. Finally, one of the most important functions of the act of pardon is its contribution to the national-political purposes. The pardon (as well as the amnesty) is often granted under certain political moments and conditions in order to pacify the state and the society. According to some authors, the pardon in some of the countries has the function to mitigate the penalization policy, and it is obvious that the mitigation i.e. decrease of the penalty depends directly from the time length of the sentence, or penalty.

\subsection{Appliance of the term amnesty in Macedonian criminal law}

Besides in Republic of Macedonia, the other post-Jugoslavian states also conduct war crime trials for the armed conflicts from January 1991 up to June 1999. It is characteristic for all trials that they last too long. Macedonia has adopted the Criminal Code in 1996, which regulates the war crimes. The Special judicial department for acts of organized crime and corruption within the Primary Court Skopje $1^{21}$ is in charge to process the war crimes. The Supreme Court and the Court of Appeal of the Republic of Macedonia are in charge for the secondary decision. The

\footnotetext{
${ }^{20}$ Bacic, F., Krivicno pravo, opci dio, Informator, Zagreb, 1980

${ }^{21}$ Zakon za izmeni i dopolnuvanja na zakonot za sudovi, clen 2. Sluzben vesnik na Republika Makedonija br. 35/2008.

Primary Court Skopje 1 is also in charge for the processes under jurisdiction of the International crime court for the former Jugoslavia (MKSJ). ${ }^{22}$ The Primary Court Skopje 1 has special equipment and access to a courtroom fulfilling the highest technical standards. 11 judges and 24 civil officers are in charge for the cases against war crime, organized crime and corruption. $^{23}$ There are no employees in the judiciary especially in charge for war crime.

The Special department for tracking and revealing of criminal activities within the Primary Public Prosecution Service, in charge of organized crime and corruption, has the ingerence to investigate and prosecute the war crime. The prosecution has its seat in Skopje, and has the jurisdiction all over Macedonia. ${ }^{24} 11$ prosecutors in total, who are also responsible for the cases against organized crime and corruption, have proceeded the cases upon charges against war crime.

Following the signing of the Ohrid Framework Agreement on 13 August 2001, which officially ended the armed conflict, four war crime processes have been imposed during 2002. ${ }^{25}$ All of the processes from the prosecution were against the members of the Albanian National Army (ONA).

In September 2002, the prosecution of MKSJ took the jurisdiction to process the four cases. Three years later the MKSJ stopped the investigation for the four cases against the members of ONA, and returned these in February 2008 to be processed in front of the Macedonian judiciary.

\footnotetext{
${ }^{22}$ Zakon za sorabotka na Republika Makedonija I Megunarodniot krivicen sud za poranesna Jugoslavija (MKSJ), clen 26. stav 2, Sluzben vesnik na Republika Makedonija, br. 73/2007

${ }^{23} \mathrm{http}$ ://osskopje1.mk/cms/FCKEditor_Upload/File/ WVr/osm.html.

${ }^{24}$ Zakon za javno obvinitelstvo, Sluzben vesnik na R. Makedonija br. 150, 12.12.2007. clen 15, stav 2.

${ }^{25}$ Fond za humanitarno pravo, BIRN I Dokumenta, Tranziciskata Pravda vo postjugoslovenskite zemji: Izvestaj za 2009. godina, str.17
} 
The Head prosecutor of MKSJ then, Carla Del Ponte, declared that the Tribunal had no other choice, because the Safety Council of UN required all investigation processes to be finished until the end of 2007. The returned cases were first translated from English and Macedonian into Albanian language, and then the Ministry of justice has submitted these cases to the Prosecution Service (June/July 2008). The Primary Public Prosecution Service, following the procedure and recording of the cases, has forwarded the materials to the Department for investigation of the Primary Court Skopje 1. At the end, by adopting the authentic interpretation of the Law on amnesty in July 2011, the legal process stopped for all four cases.

\subsubsection{Amnesty of war crime}

On 19 July 2011, in the Parliament of the Republic of Macedonia, under initiative of the Albanian political parties (Democratic Party of Albanians - DPA and the Democratic Union for Integration DUI) started the process for the majority support of the request for authentically interpretation of the Law on amnesty. On the same day, this initiative was adopted by 63 votes "for" and 29 "against", which practically terminated all judicial actions and search for prosecution justice for severe breach of the human rights during the armed conflict in Macedonia. $^{26}$

The Law on amnesty was adopted in 2002, seven months after signing of the Ohrid Framework Agreement, which enabled the amnesty of members of armed formations, which were under suspicion that have committed criminal acts during the conflict including and up to 26 September 2001. ${ }^{27}$ According to this law, the amnesty doesn't refer to defendants

\footnotetext{
${ }^{26}$ Stenografski beleski od cetvrtata sednica na Sobranieto na R.Makedonija, 19.juli. 2011.godina, str. 53.

${ }^{27}$ Zakon za amnestija, clen 1 Sluzben vesnik na R.Makedonija, br 18/2002.
}

against whom a process is being started in front of the MKSJ. In 2009 DPA submitted a request to the Government of the Republic of Macedonia for an authentic interpretation of the Law on amnesty, but the Government did not accept this proposal at that moment. ${ }^{28}$ The same request was submitted by DUI in 2011 and received a positive answer, at first from the Government, and then in the Parliament.

The authentic interpretation of the Law on amnesty provided the amnesty to be applied also to the defendants for the cases, which the MKSJ have returned to Macedonia for processing. Amnesty International has criticized this interpretation and appliance of the Law on amnesty as a breach of the international humanitarian right. The right of the victim to know the truth and the right of justice to be satisfied cannot be subject to a political agreement, and the missing persons' relatives have the right to know the truth for their nearest and dearest. ${ }^{29}$

\subsection{Appliance of the term pardon in Macedonian criminal law}

In this part, we can show some examples of appliance of the term pardon in the Macedonian criminal law. The President usually grants pardon i.e. decisions for pardon to the prisoners few times a year, for e.g. New Year, 2 August and the Independence day 8 September.

As one of the examples that shall be taken is the decision brought by the President of the Republic of Macedonia, Djordje Ivanov, when on the occasion of New Year 2013, granted pardon to 51 convicts in total.

\footnotetext{
${ }^{28}$ Stenografski beleski od cetvrtata sednica na Sobranieto na R.Makedonija, 19.juli. 2011.godina, str. 3.

${ }^{29}$ Amnesty International, "Macedonia Time to deliver justice to the victims of war crimes “, PR 1 September 2011 http://www.amnesty.org/en/formedia/press-releases/macedonija-time-deliverjustice-viktims-war-crimes-2011-09-01
} 
The President of the Republic of Macedonia, Djordje Ivanov, then, has granted pardon to 10 persons that were released from serving their prison sentence in full, and to 41 persons in part. It is an interesting statistical data that the President Djordje Ivanov has reached the record of persons to whom a pardon was granted before the national holiday on 2 August in 2011. By the decision of his cabinet the pardon was granted to 85 convicts, 19 of which in full, and 66 in part - by decreasing the prison sentence. ${ }^{30}$ Upon proposal of the Committee on pardon, working within the Presidential cabinet, Ivanov has decided in 2010 on the occasion of 2 August to grant pardon to 59 convicts, and the year before 61. This means that within three years of governing, the Chief of State has granted pardon to 205 convicts in total for Ilinden. According to the data found in the archive of the „Official Gazette“, this is the highest number of convicts, released from prison sentence, by any President of the independent Macedonia.

The record of Ivanov's predecessor, Crvenkovski, is 68 persons to whom the pardon was granted for Ilinden in 2008 or 202 persons in total during his five-year mandate as a Chief of State. Boris Trajkovski, on the other hand, was more rigorous. During his four years of acting the function President, has granted pardon for Ilinden for 75 convicts in total, which is less than Ivanov has granted pardon within one year only. From the data available for the six-year mandate of Gligorov, it is obvious that in 1992 he was as close to the number that Ivanov has reached in 2011. Eleven years ago, the first President of Macedonia has granted pardon to 74 persons in full, or in part, on 2 August, but in the other years the number of pardon granted has exceeded twenty only once. Or for the two mandates, according to the informations available, he has granted pardon to 156 convicts in total.

\footnotetext{
${ }^{30} \mathrm{http}: / /$ www.novamakedonija.com.mk/NewsDetal.a sp?vest $=811187497 \&$ id $=9 \&$ setIzdanie

\section{How to reach the grace of the President?}

There are two ways for a convicted person to reach the grace of the President, who can decrease his sentence. The first one is by a claim written to the Special committee on pardon within the Presidential cabinet. The appeal for pardon in full or in part is submitted by the prisoner himself, or by his closest relatives. The appeal for pardon can be asked by the Ministry of justice as well. The members of the Committee shall review the requests case by case and shall compose a list of convicts to whom they consider it is necessary a pardon to be granted and to what extent: in full or in part and what would the decrease of the sentence might be. The first opinion, which is not compulsory for the Presidential committee, for all requests sent to the Committee has to come from the competent Ministry. The Law on pardon lists all of the criteria that have to be considered when the Committee decides to which convict the pardon shall be granted.

The second way to grant a pardon is the so called granting pardon to a group, which is made by the President, on the occasion of determined national holidays or on special occasions. This type of pardon has the patriotic role, in general, and it represents a sign of forgiveness. It also has the educational role showing that the state has the grace even for the perpetrators of criminal acts, if the convicts prove to have changed their behaviour to a better one. This type of pardon is usually granted in Macedonia for 2 August, New Year and for 8 September.

In this case the pardon is not requested by a claim, but it comes upon proposal from the penitentiary in which the convict is serving the sentence, and which based on the behaviour of the prisoners assessed that the prisoner is ready for resocialization. In this case the prison, by granting pardon, sees an opportunity to stimulate this positive mission, but also to serve as an education to the rest of them committed a criminal act. 


\section{Controversial act of pardon}

When it comes to on pardon, abolition (specific act of pardon to a specific person even during the process of investigation) and amnesty (fully release of criminally responsibility for specific criminal acts, or under specific circumstances), whose at the end result release from penalty for the criminal act committed in Macedonia, were followed by few controversial cases.

So, in the first act of grace of the President Ivanov when he granted a pardon to a group for Ilinden 2009, one of the persons who were granted a pardon was the former director of the Electro economies in Macedonia, to whom 10 months of the prison sentence, serving in „Idrizovo“, was decreased. Afterwards, the act of pardon was withdrawn. The President has apologized to the Macedonian citizens explaining that he had no intention to grant pardon to him and that he had made a technical mistake, after which a new decision for granting a pardon to a group was published in the „Official Gazette". The lawyers had separate opinions whether an act of pardon can be withdrawn or not.

The controversial act of pardon is drawing the public's attention mostly when the President is granting pardon to members of his party. Therefore, with exemptions, in the legislature it has been suspended the possibility to the President of the State to bring alone the Oblivion Act, without performing the process for granting a pardon by law, referring to that this act is for the benefit of the republic i.e. there are special circumstances related to the person and to the criminal act, showing it is justified.

Also, due to the great number of convicts, being granted a pardon by the President, for elections' fraud and violence at the day of elections, the legislature has limited the possibility to the Chief of State to grant a pardon for such criminal acts.

\section{It is hard to forgive to the convicts}

If we compare Macedonia to the other Balkan's states in the practice of granting a pardon, it comes out that Macedonian presidents are more rigid, not just in view of the number of convicts being granted a pardon, but also in the extent of decrease of the sentence. On average, we release convicts who are having less than one year prison sentence or the sentence can be decreased from six to one year. In the other states, granting a pardon mean decrease of the sentence even for four-five years.

The most rigorous is the French president Nikolas Sarkozy who, few years ago, refuse to continue the tradition established by his predecessors Jacques Chirac and François Mitterrand who were granting pardon to a mass groups for the Bastille's day many years, and on the other hand, this was an attempt to decrease the number of prisoners in the overcrowded penitentiaries. In France there are ca. 60.000 prisoners, on average this presidential measure is affecting to ca. 3.500 prisoners per year.

\section{Conclusion}

According to the above in this study, it can be concluded that the amnesty and the act of pardon represent act of grace by the highest governmental bodies, which by applying it can release the convicts form the sentence or can replace it with a more favourable one. Besides, the amnesty and the act of pardon can cover a release from prosecution i.e. inability to start or impose criminal charges, which is actually an abolition. The amnesty and the act of pardon are almost similar legal terms, but still there are big differences between them. By granting a pardon and amnesty comes a conflict of the idea of the law with the other ideas, such as political, ethical or religious. Through the mercy in the world of law are being introduced the valuable areas in the law, the grace as a religious value and the patience as an ethical value. 
The amnesty and the act of pardon are as old as the sources of civilized society, therefore, it is no wonder the both terms are well known in almost every legal system today. Many authors agree that both terms have a strong legal influence, because they are above the verdict, while the abolition is actually even above the law itself. By granting a pardon mercy enters the law, but it is raising high above the law.

The purpose of this study was to show the appliance of the term pardon in the Republic of Macedonia, as well as the appliance of the amnesty, and to note the specific issues refer to these terms. For the future, in order to avoid controversial cases of granting a pardon abolition and amnesty, which at the end result with release from penalty for criminal act committed, it is necessary to pay special attention when deciding whether abolition, pardon or amnesty shall be granted to a person or not. Before communicating the decision for granting a pardon or amnesty for certain person, or persons, it is necessary to review it several times in order to be in accordance to the applicable regulation.

\section{References}

[1] Kambovski Vlado, Kazneno pravo poseben del, Prosvetno delo, 2003, Skopje. cit. delo 6

[2] Kambovski Vlado, Problematikata na propustanjeto vo kaznennoto pravo, 1982, Skopje,

[3] Marjanovik Gorgi, Makedonsko krivicno pravo, opst del, Prosvetno delo, 1998, Skopje

[4] Kovalev M. i kolektiv avtorov, Ugolovnoe pravo, ossobenaja cast, NORMA, 2001, Moskva

[5] Bacic, F., Krivicno pravo, opci dio, Zagreb, 1980.

[6] Frank, S., Teorija kaznenog prava, Zagreb, 1955.

[7] Henigsberg, L., Tumac akonika o sudskom krivicnom postupku za Kraljevinu Srba, Hrvata i Slovenaca od 16. februara 1929, Zagreb, 1930.
[8] Kurtovic, A., Pomilovanje, Zagreb, 2003.

[9] Kurtovic, Š., Impeachment i politicka odgovornost, Studije i clanci iz opce povijesti prava i drtave 1962-2002, Zagreb, 2002 .

[10]Rassat, M., Droit pénal, Paris, 1987.

[11]Đurcevic, Z., Povijesni razvoj kaznenopravnog položaja pocinitelja s duševnim smetnjama u Engleskoj, Zbornik PFZ, vol. 56, broj 2-3, 2006.

[12]Geerds, F., Gnade, Recht und Kriminalpolitik, J.C.B. Mohr \& Paul Siebeck, Tübingen, 1960.

[13]Pihler, S., Prilog o raspravi o pomilovanju, Pravni tivot, br. 6-7, 1987.

[14]Ustav na Republika Makedonija, Ministerstvo za Pravda, 2006

[15]Zakon za amnestija, Sluzben vesnik na Republika Makedonija, br.18 od 8 mart 2002 godina

[16]Sluzben vesnik na Republika Makedonija br.20 od 2 april 1993 godina

[17]Izmeni i dopolnuvanja na Zakon za pomiluvanje, Sluzben vesnik na Republika Makedonija br.12 od 28 januari 2009 godina

[18]Zakon za sorabotka so Megunarodniot krivicen sud na poranesna Jugoslavija (MKSJ), clen 26.stav 2, Sluzben vesnik na Republika Makedonija br.73/2007

[19] http://denesen.mk/web/?p=73095

[20]http://www.pravdiko.mk/postapka za pomiluvanje od strana na pretsedatelot na rm

[21] http://osskopje1.mk/cms/FCKEditor_Uploa d/File/WVr/osm.html.

[22] http://www.amnesty.org/en/formedia/press-releases/macedonija-timedeliver-justice-viktims-war-crimes-2011$\underline{09-01}$

[23] http://www.novamakedonija.com.mk/News Detal.asp?vest $=811187497 \&$ id $=9 \&$ setIzdan ie 